\title{
Growth of Fresh-Water Prawn Macrobrachium tenellum (Smith, 1871) Juveniles Fed Isoproteic Diets Substituting Fish Meal by Soya Bean Meal
}

\author{
Manuel García-Ulloa Gomez ${ }^{1}$, Luis Alberto López-Aceves ${ }^{1}$, Jesús Trinidad Ponce-Palafox ${ }^{2}$, \\ Hervey Rodríguez-González ${ }^{3}$ and José Luis Arredondo-Figueroa ${ }^{4}$. \\ ${ }^{1}$ Laboratorio de Ciencias Marinas; Universidad Autónoma de Guadalajara; Barra de Navidad; \\ turbotuag@hotmail.com; C.P. 48987; A.P. 3, Jalisco-México. ${ }^{2}$ Laboratorio de Bioingeniería Acuícola; Centro de \\ Investigaciones Biológicas; Universidad Autónoma del Estado de Morelos; jesús.ponce@usa.net; Avenida \\ Universidad 1001; Colonia Chamilpa; C.P. 62270; Cuernavaca - Morelos - México. ${ }^{3}$ Centro de Investigaciones \\ Biológicas del Noroeste; Mar Bermejo 195; Colonia Playa Palo de Santa Rita; C.P. 23090; A.P. 128; La Paz - Baja \\ - California Sur - México. ${ }^{4}$ Planta Experimental de Producción Acuícola; Departamento de Hidrobiología; CBS; \\ Universidad Autónoma Metropolitana Iztapalapa; afjl@xanum.uam.mx; Avenida San Rafael Atlixco 186; Colonia \\ Vicentina; Iztapalapa 09340; D.F. C.P. 55-535 - México
}

\begin{abstract}
Growth parameters (standard length, weight, specific growth rate and daily weight gain) of prawn Macrobrachium tenellum juveniles fed $40 \%$ crude protein isoproteic diets substituting fish meal with soya bean meal at various levels $(20,40,60,80$ and 100\%) were evaluated for 45 days under laboratory conditions. Experimental diets were compared with a $100 \%$ fish meal based diet. Total survival was recorded for all the treatments at the end of the experiment. There were no significant differences ( $p \geq$ $0.05)$ for all the growth parameters among the dietary treatments. The initial mean weight $(0.36 \pm 0.10 \mathrm{~g})$ increased almost three times $(1.00 \pm 0.13 \mathrm{~g})$ after 45 days. The final specific growth fluctuated from $1.82 \% \mathrm{BW} / \mathrm{d}$ for the $60 \%$ soya bean meal inclusion diet, to $2.62 \%$ for the $100 \%$ fish meal diet. The mean final survival was $91.66 \%$. Growth performance of $M$. tenellum juveniles was not affected by the dietary soya bean meal levels tested.
\end{abstract}

Key words: Growth, fresh water prawn, Macrobrachium tenellum, isoproteic diets, soya bean meal, aquaculture

\section{INTRODUCTION}

The fresh-water prawn Macrobrachium tenellum is distributed from Baja California, México, to the River Chira, in Peru, living in the rivers and estuaries along the Pacific coast (Holthius, 1980). This prawn represents a very important fishery resource and is strongly exploited by local communities (Cabrera-Jiménez et al., 1977). According to Ponce-Palafox et al. (2002) several biological characteristics favor its culture; for example, it is herbivorous, although also consumes small invertebrates and detritus (Barnes, 1977), tolerates wide variations for several water quality parameters such as dissolved oxygen (Cuevas, 1980), salinity (Aguilar et al., 1998) and

\footnotetext{
* Author for correspondence
} 
temperature (Hernández et al., 1995). The prawns mate and spawn from August to November (Guzmán, 1987), and are non-aggressive compared with the other species (Sánchez, 1976). There are few reports on the hatchery production and on growing of the juveniles (Cabrera-Jiménez et al., 1979; Martínez et al., 1980; Ponce-Palafox, 1997), indicating that prawns with an average weight of 50-60 $\mathrm{g}$ can be harvested from the sixth month onwards (Ponce-Palafox and Arana, 1999).

There are no reports on a specific diet for $M$. tenellum and a wide variety of food ingredients are commonly given, including natural food and organic manure (Ponce-Palafox and Cabanillas, 1996). In some cases, the diets used have been formulated for other aquatic species (PoncePalafox and Arana, 1999; Rodríguez-González, 1998). Ponce-Palafox et al. (2002) indicated the need to develop a cost-effective and nutritionally balanced formulated diet, specific for M. tenellum, in order to optimize its production.

In the formulated practical diets in the aquaculture, protein is the most expensive energy component, and its quality represents a very important nutritional aspect. The use of alternative protein sources in the culture of some crustacean species of commercial importance to reduce feed costs has been reported (Akiyama, 1988; Piedad-Pascual et al., 1990; García-Ulloa et al., 2003).

It is accepted that soya bean meal is available worldwide and is cheaper than fish meal. Reigh et al. (1990) and Cabanillas et al. (2001) have proved that soya bean meal is a high quality supplement and is well digested by some crustacean. Campaña et al. (2000) demonstrated that soya bean meal was readily digested by the redclaw crayfish Cherax quadricarinatus, coinciding with the observations of Tidwell et al. (1993) for the Giant Malaysian prawn Macrobrachium rosenbergii. Since there is no information on the possible use of soya bean meal in the formulated diets for the growth of $M$. tenellum juveniles, the objective of the present work was to evaluate different dietary protein contents on its growth performance, replacing fish meal totally or partially with soya bean meal, as the main protein source.

\section{MATERIALS AND METHODS}

\section{Experimental design}

$M$. tenellum $(\mathrm{n}=250)$ was collected from irrigation channels located at the coastal side of
Colima State, Mexico, with a mean body weight of $0.36 \pm 0.10 \mathrm{~g}$, and transported to the laboratory in a 500-L fiber glass tank. After arrival, the prawns were held in two 400-L tanks and acclimate for one week to the laboratory conditions. Water temperature was maintained at $27 \pm 1.2{ }^{\circ} \mathrm{C}$. A 12 $\mathrm{L}: 12 \mathrm{D}$ daily photoperiod was adjusted throughout this period. Aerated fresh-water was supplied to each container and $50-80 \%$ of the total water volume was changed. Organisms were fed ad libitum two times daily (09:30 and 18:30 h) with a commercially pelleted shrimp diet $\left(\mathrm{AS}^{\circledR}\right.$ Aceitera La Junta, S. A. de C. V., Jalisco, México) with $40 \%$ crude protein, and feces and food waste were siphoned. After acclimatizing to the laboratory conditions, 120 prawn were randomly selected from the original group and stocked in 10-L plastic containers (filled to 8-L with fresh-water) in a closed recirculation system (water flow rate $=0.25$ $1 / \mathrm{min}$ ), as reported by García-Ulloa and Hernández-Garciabada (2003), at an initial density of five prawns per container with four repetition per diet. Five small PVC tubes (1/4" diameter) were placed into each container. Before the study began, animals were fed ad libitum with the experimental diets for two weeks.

\section{Diet formulation}

Six isoproteic diets with $40 \%$ crude protein were formulated based on the calculations with the Pearson Square method (Houser and Akiyama, 1997) and using practical and semi-purified ingredients (Table 1 and 2). Dietary protein was supplied by the Peruvian fish meal, soya bean meal or an isoproteic mixture of soya bean and fish meal, to obtain graded levels of each protein, as follows: $100 \%$ fish protein (diet $1 ; 0 \%), 80 \%$ fish protein: $20 \%$ soya bean protein (diet $2 ; 20 \%$ ), $60 \%$ fish protein: $40 \%$ soya bean protein (diet 3; $40 \%$ ), $40 \%$ fish protein: $60 \%$ soya bean protein (diet $4 ; 60 \%$ ), $20 \%$ fish protein: $80 \%$ soya bean protein (diet $5 ; 80 \%$ ), and $100 \%$ soya bean protein (diet 6; 100\%).

Feedstuffs were grounded and sieved through a $100-\mu$ sieve so that all the ingredients were of uniform size. Then, ingredients were mixed in a domestic blender (MOULINEX ${ }^{\circledR}$, México, D. F.) for $30 \mathrm{~min}$, and oil was gradually added to the dry mix. Enough water was added to make stiff dough. The wet mixture was pressure pelleted through a meat grinder, steamed for $5 \mathrm{~min}$, and dried in a draft oven at $60{ }^{\circ} \mathrm{C}$ overnight or until the pellets contained around $10 \%$ moisture. Finally, diets 
were kept in plastic bags and stored $\left(5^{\circ} \mathrm{C}\right)$ until used.

Table 1 - Proximate analysis of the dietary protein sources (\%, dry weight basis).

\begin{tabular}{lcc}
\hline Proximate analysis & Soya bean meal & Peruvian fish meal \\
\hline Moisture & 10.8 & 6.7 \\
Crude protein & 46.9 & 58.9 \\
Ether extract & 0.2 & 2.3 \\
Fiber & 5.0 & 2.5 \\
Ash & 6 & 20 \\
Nitrogen-free extract & 31 & 9.6 \\
\hline
\end{tabular}

Table 2 - Formulation (\% of total) and proximate composition of all experimental diets used in fish meal replacement study.

\begin{tabular}{lcccccc}
\hline $\begin{array}{l}\text { Ingredients } \\
\text { (\%) }\end{array}$ & \multicolumn{7}{c}{ Diet (percentage replacement) } \\
& $\mathbf{1}^{\mathbf{1}}$ & $\mathbf{2}$ & $\mathbf{3}$ & $\mathbf{4}$ & $\mathbf{5}$ & $\mathbf{6}$ \\
& $(\mathbf{0 \%})$ & $\mathbf{( 2 0 \% )}$ & $\mathbf{( 4 0 \% )}$ & $\mathbf{( 6 0 \% )}$ & $\mathbf{( 8 0 \% )}$ & $\mathbf{( 1 0 0 \% )}$ \\
\hline${\text { Soya bean } \text { meal }^{2}}_{\text {Fish meal }^{3}}$ & 52.0 & 10.0 & 20.0 & 31.0 & 41.0 & 52.0 \\
Rice bran $^{4}$ & 19.3 & 19.3 & 32.0 & 21.0 & 11.0 & \\
Wheat meal $^{5}$ & 19.5 & 19.5 & 19.3 & 19.3 & 19.3 & 19.3 \\
${\text { Vitamin } \text { mix }^{6}}_{\text {Fish oil }^{7}}$ & 2.0 & 2.0 & 2.0 & 19.5 & 19.5 & 19.5 \\
Salt $^{8}$ & 6.0 & 6.0 & 6.0 & 2.0 & 2.0 & 2.0 \\
Binder $^{9}$ & 0.2 & 0.2 & 0.2 & 0.0 & 6.0 & 6.0 \\
& 1.0 & 1.0 & 1.0 & 1.0 & 0.2 & 0.2 \\
Protein & Proximate composition $(\%$, dry weight basis) & & 1.0 & 1.0 \\
Lipid & 40.8 & 39.8 & 39.5 & 40.3 & 39.6 & 39.4 \\
Fiber & 4.0 & 6.1 & 5.8 & 4.4 & 5.2 & 6.2 \\
Ash & 4.9 & 1.6 & 1.5 & 1.2 & 1.6 & 5.9 \\
N-free extract & 10.9 & 8.7 & 7.9 & 7.3 & 6.2 & 5.2 \\
Dry matter & 33.2 & 37.0 & 39.8 & 43.5 & 42.3 & 41.1 \\
Moisture & 93.7 & 93.2 & 94.5 & 96.7 & 94.9 & 94.8 \\
\hline
\end{tabular}

${ }^{1}$ Fish protein/soya bean meal ratios: $0 \%=100 \%$ fish meal, diet $1 ; 20 \%=80 \%$ fish meal $/ 20 \%$ soya bean meal, diet $2 ; 40 \%=60 \%$ fish meal $/ 40 \%$ soya bean meal, diet $3 ; 60 \%=40 \%$ fish meal $/ 60 \%$ soya bean meal, diet $4 ; 80 \%=20 \%$ fish meal $/ 80 \%$ soya bean meal, diet $5 ; 100 \%=100 \%$ soya bean meal, diet 6 .

${ }^{2}$ Source: soya bean meal (46.9\% protein), local vendor.

${ }^{3}$ Source: Peruvian fish meal (58.9\% protein), Fondeport, Manzanillo, México.

${ }^{4}$ Source: rice bran (14\% protein), Arrocera de Occidente, S. A. de C. V., Zapopan, Jalisco, México.

${ }^{5}$ Source: wheat flour (15\% protein), Molino Central, S. A. de C. V., Guadalajara, Jalisco, México.

${ }^{6}$ Source: vitamin mix, Geymix ${ }^{\circledR}$ Plus, Novartis Salud Animal, S. A. de C. V., México, D. F., guaranteed analysis (per $500 \mathrm{~g}$ of mix) was: vitamin A (palmitate) 156,250 IU; vitamin D-3, 150,000 IU; vitamin E, $36 \mathrm{IU}$; riboflavin, $88 \mathrm{mg}$; d-pantothenic acid, $160 \mathrm{mg}$; niacin, $360 \mathrm{mg}$; cyanocobalamin, $0.5 \mathrm{mg}$; thiamine, $18.7 \mathrm{mg}$; menadione, $19.2 \mathrm{mg}$; folic acid, $3.0 \mathrm{mg}$; ascorbic acid, 25,000 mg; sacarose, $100 \mathrm{~g}$.

${ }^{7}$ Source: fish oil, PULSE OMEGA 3, Seven Seas ${ }^{\circledR}$, Health care Ltd., Scotland, UK.

${ }^{8}$ Source: unpurified salt, local vendor.

${ }^{9}$ Source: alginic acid, Bioxon de México, S. A. de C. V., Oaxaca, México. Dissolved in 35 parts hot $\left(80^{\circ}\right.$ C) distilled water before mixing with diet.

${ }^{10}$ Represent the mean of three samples.

Three samples from each batch were pooled and analyzed for the proximal composition (Table 2). Crude protein was determined by using the Kjeldahl method (APHA, 1989), crude lipid was extracted with anhydrous ether in a Soxtec (Bligh and Dyer, 1959). Ash was determined by using a muffle furnace (AOAC, 1984) and crude fiber by the phenol-sulphuric acid method (Myklestad and Haug, 1972). During the experiment, a quantity of food equal to $10 \%$ of the animal biomass in each 
container was fed per day (twice daily, 09:00 and 17:00 hours). The relative quantity of food remaining in each container after the feeding was observed so that the ration size could be adjusted to minimize the waste. Diets seemed equally palatable as determined by visual inspection $1 \mathrm{~h}$ after the feeding.

\section{Growth evaluation}

Individual standard length $(\mathrm{cm})$ and wet weight $(\mathrm{g})$ were determined at the beginning of the experiment and each two weeks for 45 days. Prior to weighing, prawns were placed on absorbent paper to remove excess of water. Specific growth rate (SGR, \% body weight/d) was calculated from $\mathrm{SGR}=100 \mathrm{X}(\ln \mathrm{Wf}-\ln \mathrm{Wi}) / \mathrm{t}$, where $\mathrm{Wf}=$ mean weight at the end of the period, $\mathrm{Wi}=$ mean weight at the beginning of the period, and $t=$ time in days of the period (Ricker, 1979). Mean daily weight gain (MDWG, g/d) was calculated from MDWG = (Wf - Wi)/t. Food conversion ratio (FCR) was obtained from $\mathrm{FCR}=\mathrm{g}$ feed consumed $/ \mathrm{g}$ wet weight gained (Al Hafedh et al., 1999). Final survival per treatment was also recorded.

\section{Statistical analysis}

Statistical analysis was carried out according to Montgomery (1984). Data were tested for the normality and variance homogeneity (Kolgomorov-Smirnov's test). One-way ANOVA was used to test data, followed by post-hoc Tukey's test to separate significantly different mean values. A significance level of 0.05 was retained for each test. Arcsin transformations were applied to survival percentages before analysis (Sokal and Rohlf, 2000). Procedures available in Statgraphics Plus 5.0 were used to conduct analyses.

\section{RESULTS}

The data pertaining to mean body weight, length, SGR and survival are presented in Table 3. Prawns from all the treatments registered an increase in length and weight (Fig. 1).

Prawns in all the experimental groups grew at the rates that were consistent with the values routinely. Statistical differences in the mean final body weight ( $\mathrm{df}=5 ; \mathrm{F}=6.95 ; \alpha \leq 0.05$ ), mean weekly weight gain ( $\mathrm{df}=5 ; \mathrm{F}=8.95 ; \alpha \leq 0.05)$ and specific growth rate $(\mathrm{df}=5 ; \mathrm{F}=3.85 ; \alpha \leq 0.05)$ among the treatments were detected after the fourth week of the feeding.

Table 3 -. Fresh-water prawn (M. tenellum) growth and feed performance in an indoor flow-through culture system over 45 experimental days, and fed on isoproteic diets containing various fish meal and soya bean meal levels. Values within a row sharing a common superscript are not significantly different (Tukey's test; $\mathrm{P} \leq 0.05$ ).

\begin{tabular}{|c|c|c|c|c|c|c|}
\hline Dietary treatment & $\begin{array}{c}1^{1} \\
(0 \%)\end{array}$ & $\begin{array}{c}2 \\
(20 \%) \\
\end{array}$ & $\begin{array}{c}3 \\
(40 \%) \\
\end{array}$ & $\begin{array}{c}4 \\
(60 \%) \\
\end{array}$ & $\begin{array}{c}5 \\
(80 \%) \\
\end{array}$ & $\begin{array}{c}6 \\
(100 \%) \\
\end{array}$ \\
\hline \multirow[t]{2}{*}{ Mean initial body weight $(\mathrm{g})$} & $0.37^{\mathrm{a}}$ & $0.35^{\mathrm{a}}$ & $0.32^{\mathrm{a}}$ & $0.37^{\mathrm{a}}$ & $0.39^{\mathrm{a}}$ & $0.38^{\mathrm{a}}$ \\
\hline & $(0.11)$ & $(0.08)$ & $(0.09)$ & $(0.11)$ & $(0.10)$ & $(0.11)$ \\
\hline \multirow{2}{*}{ Mean final body weight (g) } & $0.95^{\mathrm{a}}$ & $1.09^{\mathrm{a}, \mathrm{b}}$ & $0.87^{\mathrm{a}}$ & $0.80^{\mathrm{a}}$ & $1.15^{\mathrm{a}, \mathrm{b}}$ & $1.14^{\mathrm{a}, \mathrm{b}}$ \\
\hline & $(0.27)$ & $(0.49)$ & $(0.51)$ & $(0.50)$ & $(0.60)$ & $(0.73)$ \\
\hline \multirow[t]{2}{*}{ Mean initial body length $(\mathrm{cm})$} & $2.52^{\mathrm{a}}$ & $2.54^{\mathrm{a}}$ & $2.50^{\mathrm{a}}$ & $2.54^{\mathrm{a}}$ & $2.42^{\mathrm{a}}$ & $2.39^{\mathrm{a}}$ \\
\hline & $(0.29)$ & $(0.22)$ & $(0.26)$ & $(0.27)$ & $(0.24)$ & $(0.21)$ \\
\hline \multirow[t]{2}{*}{ Mean final body length $(\mathrm{cm})$} & $3.10^{\mathrm{a}}$ & $3.53^{\mathrm{a}}$ & $3.32^{\mathrm{a}}$ & $3.26^{\mathrm{a}}$ & $3.60^{\mathrm{a}}$ & $3.50^{\mathrm{a}}$ \\
\hline & $(0.35)$ & $(0.56)$ & $(0.50)$ & $(0.63)$ & $(0.57)$ & $(0.76)$ \\
\hline \multirow[t]{2}{*}{ Mean weekly weight gain (g/week) } & $0.098^{\mathrm{a}, \mathrm{b}}$ & $0.112^{\mathrm{a}, \mathrm{b}}$ & $0.077^{\mathrm{a}}$ & $0.011^{\mathrm{a}}$ & $0.119^{a, b}$ & $0.133^{\mathrm{a}, \mathrm{b}}$ \\
\hline & $(0.014)$ & $(0.007)$ & $(0.035)$ & $(0.028)$ & $(0.014)$ & $(0.063)$ \\
\hline \multirow{2}{*}{ Specific growth rate $(\% / d)$} & $2.21^{\mathrm{a}}$ & $2.44^{\mathrm{a}, \mathrm{b}}$ & $1.82^{\mathrm{a}}$ & $1.88^{\mathrm{a}}$ & $2.54^{\mathrm{a}, \mathrm{b}}$ & $2.62^{a, b}$ \\
\hline & $(0.26)$ & $(0.12)$ & $(0.67)$ & $(0.54)$ & $(0.23)$ & $(0.78)$ \\
\hline \multirow[t]{2}{*}{ Feed conversion ratio } & $1.32^{\mathrm{a}}$ & $1.41^{\mathrm{a}}$ & $1.47^{\mathrm{a}}$ & $1.51^{\mathrm{a}}$ & $1.34^{\mathrm{a}}$ & $1.37^{\mathrm{a}}$ \\
\hline & $(0.12)$ & $(0.21)$ & $(0.18)$ & $(0.25)$ & $(0.23)$ & $(0.23)$ \\
\hline \multirow[t]{2}{*}{ Survival (\%) } & $90^{\mathrm{a}}$ & $95^{\mathrm{a}}$ & $95^{\mathrm{a}}$ & $85^{\mathrm{a}}$ & $95^{\mathrm{a}}$ & $90^{\mathrm{a}}$ \\
\hline & $(10.0)$ & $(8.66)$ & $(8.66)$ & $(8.66)$ & $(8.66)$ & $(10.0)$ \\
\hline
\end{tabular}

${ }^{\mathrm{P}}$ Fish protein/soya bean meal ratios: $0 \%=100 \%$ fish meal, diet $1 ; 20 \%=80 \%$ fish meal $/ 20 \%$ soya bean meal, diet $2 ; 40 \%=60 \%$ fish meal $/ 40 \%$ soya bean meal, diet $3 ; 60 \%=40 \%$ fish meal $/ 60 \%$ soya bean meal, diet $4 ; 80 \%=20 \%$ fish meal $/ 80 \%$ soya bean meal, diet $5 ; 100 \%=100 \%$ soya bean meal, diet 6 .

$\mathrm{n}=5$ prawns for each diet with four repetitions (20 per diet).

Values in parentheses indicate \pm standard deviation. 


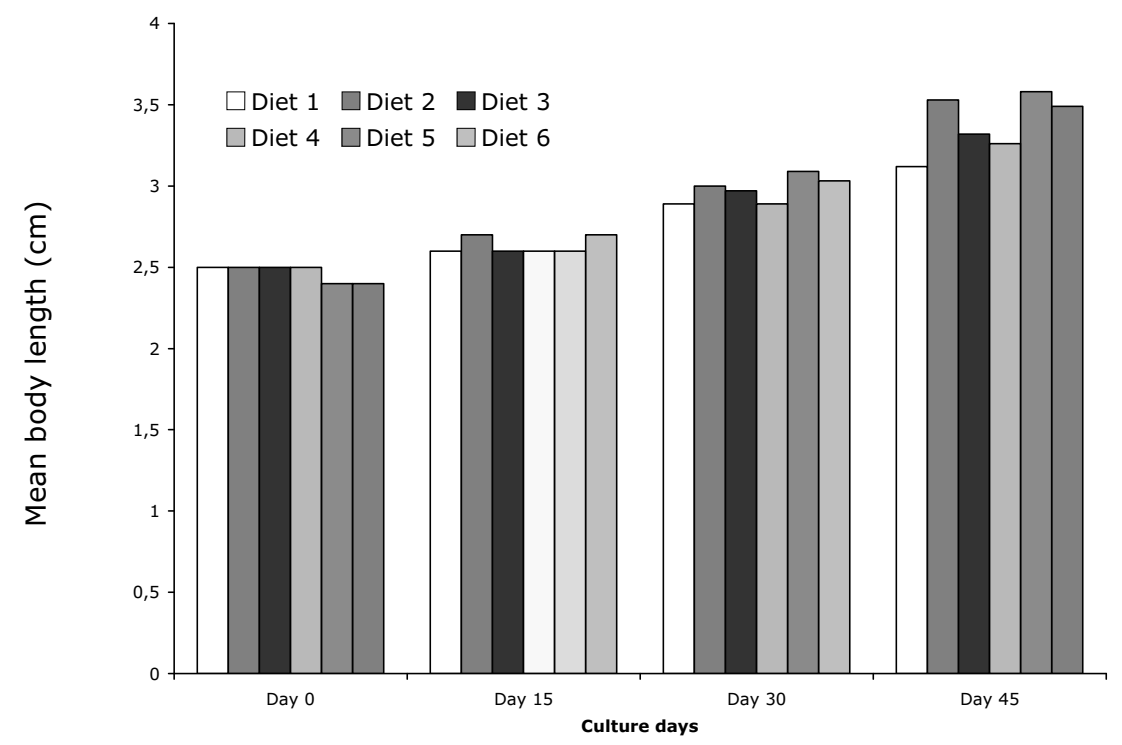

A)

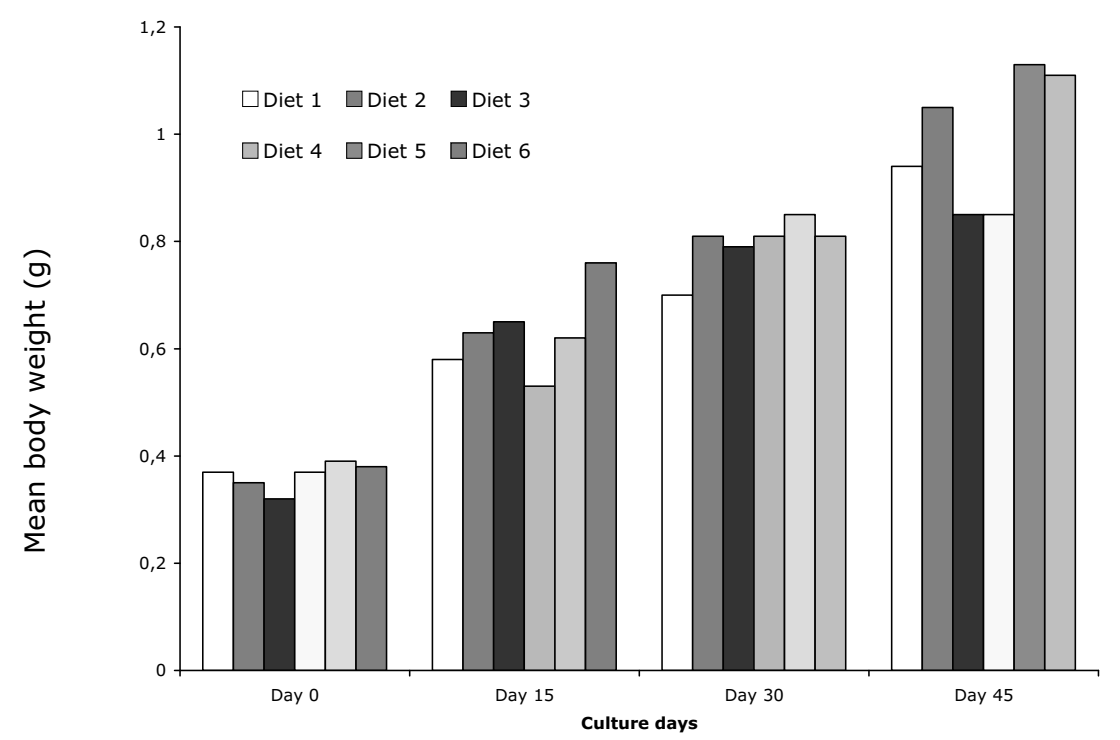

B)

Figure 1 - Mean final length (cm, A) and weight (g, B) of M. tenellum juveniles fed isoproteic diets substituting fish meal with soya bean meal. Fish protein/soya bean meal ratios: $0 \%=100 \%$ fish meal, diet $1 ; 20 \%=80 \%$ fish meal $/ 20 \%$ soya bean meal, diet $2 ; 40 \%=$ $60 \%$ fish meal $/ 40 \%$ soya bean meal, diet $3 ; 60 \%=40 \%$ fish meal $/ 60 \%$ soya bean meal, diet $4 ; 80 \%=20 \%$ fish meal $/ 80 \%$ soya bean meal, diet $5 ; 100 \%=100 \%$ soya bean meal, diet 6 . Mean initial length and wet weight $=2.48 \pm 0.24 \mathrm{~cm}$ and $0.36 \pm 0.10 \mathrm{~g}$, respectively.

No significant differences in the mean initial body weight ( $\mathrm{df}=5 ; \mathrm{F}=0.44, \alpha \geq 0.05$ ), mean initial and final body length ( $\mathrm{df}=5 ; \mathrm{F}=0.35, \alpha \geq 0.05$ and $\mathrm{df}=5 ; \mathrm{F}=0.36 ; \alpha \geq 0.05$ respectively), Feed conversion factor ( $\mathrm{df}=5 ; \mathrm{F}=0.36, \alpha \geq 0.05)$ and survival ( $\mathrm{df}=5 ; \mathrm{F}=0.76, \alpha \leq 0.05)$ were observed. Although the overall growth response of the diets $5(80 \%)$ and $6(100 \%)$ were higher than those obtained for the rest of the diets, these differences were not significant. The SGR ranged from $1.82 \pm$ 
$0.67 \% \mathrm{BW} / \mathrm{d}$ for the diet $3(40 \%)$, to $2.62 \pm 0.78$ for the diet $6(100 \%)$. Prawns fed with the diet 6 $(100 \%)$ obtained the highest weekly growth $(0.133$ $\pm 0.063 \mathrm{~g})$. FCR among the diets detected at the end of the experiment was on average $1.4 \pm 0.27$ for all the treatments. Final survival fluctuated from $85 \%$ for the diet $4(60 \%)$, to $95 \%$ for the diets $2(20 \%), 3(40 \%)$ and $5(80 \%)$.

\section{DISCUSSION}

After failed attempts for developing a Giant Malaysian prawn $M$. rosenbergii industry in México (Ponce-Palafox et al., 2002; García-Ulloa, 1997), the culture of native prawn species in the farms turned an important activity for the local aquaculture industry. According to Ponce-Palafox et al. (2002), M. americanum and M. tenellum are native fresh water prawns species with aquaculture potential in the Mexican Pacific coast. For $M$. tenellum, there are some studies on physiology (Signoret et al., 1997; Hernandez et al., 1995; 1996), biology (Román-Contreras, 1979) and reproduction (Rodríguez-González, 1998), but information about nutrition is scarce.

Since plant protein meals are cheaper than animal protein sources, much research has been focused in substituting animal protein with the plant protein meals (Akiyama, 1988; Kikuchi, 1999). However, it has been proved that the dietary inclusion of plant protein meal, generally reduce growth and feed efficiency in fish and shellfish species (Cowey et al., 1971; Akiyama et al., 1989). In this study, growth performance and survival of $M$. tenellum juveniles fed with the soya bean meal based diets, were similar to the values found for the $100 \%$ fish meal diet, suggesting this prawn was capable to efficiently utilize soya bean meal in the formulated diets under the laboratory conditions. However, the source and quality of the soya bean meal should be taken into consideration when a formulated diet is elaborated. PiedadPascual et al. (1990), Tidwell et al. (1993) and Reigh et al. (1993) reported the ability to utilize soya bean meal as dietary protein supplement for some crustaceans, but in those cases, growth performance was not improved in comparison with fish meal diets, possibly due to the presence of active antimetabolites in soya bean that had been incompletely heat-processed (García-Ulloa, 1998), trypsin inhibitors (Ayet et al., 1996), or the amino acid deficiencies in soya bean (Reed and D'Abramo, 1989).

The mean SGR in the present study ranged from $1.82 \pm 0.67 \% \mathrm{BW} / \mathrm{d}$ for the diet $3(40 \%)$, to $2.62 \pm$ 0.78 for the diet $6(100 \%)$ respectively, being similar to those observed by Jones (1988), and Meade and Watts (1995) for crayfish juveniles fed formulated diet, but lower than that obtained by García-Ulloa et al. (2003) for Cherax quadricarinatus juveniles, including various soya bean meal levels in the diet. After 45 days, organisms displayed external traits (CabreraJiménez, 1983) and mating behavior, possibly affecting the somatic growth of prawns (mainly in females), which could partially explain the low MDWG obtained. Although there were no differences among the diets, the FCR's in all treatments were higher $(>1.3)$ compared with those reported by Jones et al. (1996) and Cortés-Jacinto et al. (2003), working with juvenile crayfish fed with balanced feeds. Since there was no information related to the M. tenellum nutritional requirements, the results might not be properly compared with the above-mentioned studies due to differences in species, diets and culture conditions used.

The mean final survival averaged $91.66 \%$ for all the treatments. For other fresh water crustaceans (Jones, 1995; Rouse et al., 1991), the use of artificial refuges such as the small PVC tubes placed into the culture containers, offered protection to the prawns during the moulting process, probably contributing to the high survival obtained.

In conclusion, results indicate that the growth of M. tenellum juveniles was not affected with the dietary inclusion of soya bean meal at the levels tested. However, further trials would be necessary to define the adequate inclusion level in its diet in order to develop a cost-effective and nutritionally balanced formulated diet for the commercial prawn aquaculture. In addition, the natural food contribution under pond-culture conditions should be also considered.

\section{RESUMO}

Os parâmetros do crescimento (comprimento padrão, peso, taxa de crescimento específica e ganho diário do peso) de juveniles do Macrobrachium tenellum alimentaram a $40 \%$ a proteína crua as dietas isoproteic que substituem a 
refeição de peixes com feijão de soya a refeição nos vários níveis $(20,40,60,80$ e 100\%) foi avaliada por 45 dias sob condições do laboratório. As dietas experimentais foram comparadas com uma dieta baseada da refeição de peixes de $100 \%$. A sobrevivência total foi gravada para todos os tratamentos no fim da experiência. Não havia nenhuma diferença significativa $(\mathrm{p} \geq 0.05)$ para todos os parâmetros do crescimento entre os tratamentos dietéticos. $\mathrm{O}$ peso médio inicial $(0.36 \pm 0.10 \mathrm{~g})$ aumentado quase três vezes $(1.00 \pm 0.13 \mathrm{~g})$ após 45 dias da cultura. O crescimento específico final flutuou de $1.82 \%$ $\mathrm{BW} / \mathrm{d}$ para a dieta do inclusion da refeição do feijão de soya de $60 \%$, a $2.62 \%$ obtidos para a dieta da refeição de peixes de $100 \%$. A sobrevivência final média foi de $91.66 \%$. O desempenho do crescimento de juveniles do $M$. tenellum não foi afetado pelos níveis dietéticos da refeição do feijão de soya testados.

\section{REFERENCES}

Aguilar, M.; Díaz, F. and Buckle, L. F. (1998), The effect of salinity on oxygen consumption and osmoregulation of Macrobrachium tenellum. Marine Fresh. Behav. Physiol., 31, 105-113.

Akiyama, D. (1988), Soya bean meal utilization by marine shrimp. In-AOCS World Congress on Vegetable Protein Utilization in Human Food and Animal Feedstuffs, Singapore, 2-7 Oct., 1988. Am. Soya Bean Assoc., Singapore, 27 p.

Akiyama, D.; Cacho, S. R.; Lawrence, A. L. and Robinson, E. H. (1989), Apparent digestibility of feedstuffs by the marine shrimp Penaeus vannamei Boone. Nippon Suisan Gakkaishi, 55, 91-98.

Al-Hafedh, Y. S.; Siddiqui, A. Q. and Saiady, M. Y. (1999), Effects of dietary protein levels on gonad maturation, size and age at first maturity, fecundity and growth of Nile tilapia. Aquaculture, International, 7, 319-332.

A.O.A.C. (1984), Official Methods of Analysis. Association of Official Analytical Chemists (AOAC). Arlington, Vancouver.

A.P.H.A. (1989), Standard Methods for the Examination of Water and Wastewater. $14^{\text {th }}$ Ed. American Public Health Association, Washington, DC, USA.

Avault, J. W. (1996), Fundamentals of aquaculture. A step-by-step guide to commercial aquaculture. AVA Publishers. Baton Rouge, Los Angeles, USA.
Ayet, G.; Muzquiz, M.; Burbano, C.; Robredo, L. M.; Cuadrado, C. and Price, K. R. (1996), Determinations of saponins in the main legumes cultivated in Spain. Food Sci. Technol. Int., 2, 95-100.

Barnes, R. D. (1977), Zoología de los Invertebrados. Nueva Editorial Interamericana, $3^{\mathrm{a}}$. Ed. México, D. F.

Bligh, E. G. and Dyer, W. I. (1959), A rapid method of total lipid extraction and purification. Can. J. Biochem. Physiol., 37, 911-917.

Cabanillas-Beltrán, H., Ponce-Palafox, J.T., MartínezPalacios, C.A.; Chávez-Sánchez, M.C. and Ross, L. (2001), Comparison of the digestibility of diets based on fish meal and soya bean meal in Litopenaeus vannamei Boone 1931, using different temperatures and salinities for culture. Ciencias Marinas, 27(4), 577-593.

Cabrera-Jiménez, J. (1983), Carácter práctico para diferenciación de sexos en Macrobrachium tenellum (Crustacea: Decapoda: Natantia). Rev. Biol. Trop., 1, 159-160.

Cabrera-Jiménez, J.; Guzmán, M. and Kensler, C. (1977), Macrobrachium fishery and market in México. In-Shrimp and prawn farming in the western hemisphere, eds. Hanson, J. and Goodwin, G. Dowden, Hutchington and Ross, Inc. USA, pp. 315316.

Cabrera-Jiménez, J.; Chávez, C. and Martínez, C. (1979), Fecundidad y cultivo de Macrobrachium tenellum (Smith) en el laboratorio. An. Inst. Cienc. del Mar y Limnol., UNAM, 50, 127-152.

Campaña, T. A.; Villarreal, C. H.; Civera, C. V. and Martínez, C. L. R. (2000), Digestibilidad proteica de diferentes ingredientes y su efecto en los parámetros de producción de juveniles y preadultos de langosta Australiana de agua dulce Cherax quadricarinatus. In-Memories of $V$ International Symposium on Aquaculture Nutrition, eds. Cruz-Suárez, L. E.; Rique-Marie, D.; Tapia-Salazar, M.; Olvera-Novoa, M. and Civera-Cerecedo R. Mérida Yucatán, México, 72 pp.

Cortés-Jacinto, E.; Villarreal-Colmenares, H.; CiveraCerecedo, R. and Martínez-Córdova, R. (2003), Effect of dietary protein level on growth and survival of juvenile freshwater crayfish Cherax quadricarinatus (Decapoda: Parastacidae). Aquacult. Nutr., 9, 207-213.

Cowey, C. B.; Pope, J. A.; Andron, J. W. and Blair, A. (1971), Studies on the nutrition of marine flatfish. Growth of the plaice Pleuronectes platessa on diets containing proteins derived from plants and other sources. Mar. Biol., 10, 145-153.

Cuevas, F. (1980), Tasa respiratoria del langostino Macrobrachium tenellum (Smith). Bachellor Thesis, Facultad de Ciencias, Universidad Nacional Autónoma de México, México, D.F.

García-Ulloa, G. M. (1997), ¿Qué ha pasado con la producción de crustáceos de agua dulce en México? Panorama Acuícola Magazine, 2, 26. 
García-Ulloa, G. M. (1998), Uso de harinas derivadas de subproductos agrícolas en la producción de biomasa del branquiópodo Artemia franciscana, Kellog, 1906. PhD Thesis, Universidad de Colima, Colima, México.

García-Ulloa, G. M.; López-Chavarín, H. M.; Rodríguez-González, H. and Villarreal-Colmenares, H. (2003), Growth of redclaw crayfish Cherax quadricarinatus (Von Martens 1868) (Decapoda:Parastacidae) juveniles fed isoproteic diets with partial or total substitution of fish meal by soya bean meal: preliminary study. Aquacult. Nutr., 9, 2531.

García-Ulloa, G. M. and Hernández-Garciabada, F. (2003), Effect of dietary inclusion of decapsulated Artemia cysts on growth and survival of red tilapia (Oreochromis mossambicus) fry and its subsequent fingerling production. J. Aquacult. Trop., 18,139-151.

Guzmán, A. M. (1987), Biología, ecología y pesca del langostino Macrobrachium tenellum (Smith, 1971), en las lagunas costeras del estado de Guerrero, México. PhD Thesis, Instituto de Ciencias del Mar y Limnología, Universidad Nacional Autónoma de México, México, D.F.

Hernández, R. M.; Buckle, L. F. and Díaz, H. F. (1995), Preferred temperature of Macrobrachium tenellum (Crustacea: Palaemonidae). Riv. Ital. Acquacol., 30, 93-96.

Hernández, R. M.; Fernando, L.; Ramírez, B. and Díaz, H. F. (1996), Critical thermal maximum of Macrobrachium tenellum. J Therm. Biol., 21, 139143.

Holthius, L. B. (1980), FAO species catalogue. Shrimps and prawns of the world. FAO Fisheries Synopsis, 1, 271.

Houser, R. H. and Akiyama, D. M. (1997), Feed formulations principles. In-Crustacean Nutrition, Advances in World Aquaculture, eds. D'Abramo, L. R.; Conklin, D. E. and Akiyama, D. M. The World Aquaculture Society, Baton Rouge, Louisiana, USA pp. 493-519.

Jones, C. M. (1988), Aquaculture potential of Cherax quadricarinatus: research objectives and preliminary results. In-Proceedings of the $1^{\text {st }}$. Australian Shellfish Aquaculture Conference, eds. Evans, L. H. and O'Sullivan, D. Perth, Australia, 23 Oct., vol. 1, pp. 73-78.

Jones, C. M. (1995), Production of juvenile redclaw crayfish, Cherax quadricarinatus (von Martens) (Decapoda: Parastacidae). III. Managed pond production trials. Aquaculture, 138, 247-255.

Jones, P. L.; De Silva, S. S. and Mitchell, D. B. (1996), The effect of dietary protein source on growth and carcass composition in juvenile Australian freshwater crayfish. Aquacult Int., 4, 361-367.
Kikuchi, K. (1999), Partial replacement of fish meal with corn gluten meal in diets for Japanese flounder Paralichthys olivaceus. J. World Aquacult. Soc., 30, 357-363.

Martínez, P. C.; Chávez, C. and Palomo, G. (1980), Avance sobre el semicultivo del langostino Macrobrachium tenellum (Smith). In-Memorias del Segundo Simposio Latinoamericano de Acuicultura, Departamento de Pesca, México, pp. 643-662.

Meade, M. E. and Watts, S. A. (1995), Weight gain and survival of juvenile Australian crayfish Cherax quadricarinatus fed formulated feeds. J. World Aquacult. Soc., 26, 469-474.

Montgomery, D.C. (1984), Design and analysis of experiments. John Wiley and Sons, New York.

Myklestad, S. and Haug, A. (1972), Production carbohydrates by the marine diatom Chaetoceros affini var. wille (Gran) Husted. I. Effect of the concentration of nutrients in the culture medium. $J$. Exp. Mar. Biol. Ecol., 9, 125-136.

Piedad-Pascual, F.; Cruz, E. M. and Sumalangcay, A. Jr. (1990), Supplemental feeding of Penaeus monodon juveniles with diets containing various levels of defatted soya bean meal. Aquaculture, 89, 183-191.

Ponce-Palafox, J. T. (1997), Current and future trend in freshwater prawn culture in México. In-Island Aquaculture and Tropical Aquaculture, Les Trois Islets (Martinique), World Meeting Number 972 5004, 4-9 May, 1997.

Ponce-Palafox, J. T. and Cabanillas, H. B. (1996), La investigación en el cultivo de langostino en México al término de 1995. In-Memorias de las Reuniones Técnicas de la Red Nacional de Investigación para Acuicultura en Aguas Continentales. Pátzcuaro, Michoacán, México, Instituto Nacional de la Pesca, pp. 103-111.

Ponce-Palafox, J. T. and Arana, F. (1999), El cultivo de los langostinos nativos del Pacífico Americano $M$. tenellum (Smith, 1871) y M. americanum (Bate, 1968), In-Tercera Reunión de Investigadores de Aguas Continentales. Instituto Nacional de la Pesca, Dirección de Acuacultura. Cuernavaca, Morelos, México, p. 12.

Ponce-Palafox, J. T.; Arana-Magallón, F. C.; Cabanillas-Beltrán, H. and Esparza-Leal, H. (2002), Bases biológicas y técnicas para el cultivo de los camarones de agua dulce nativos del Pacífico Americano Macrobrachium tenellum (Smith, 1871) y M. americanum (Bate, 1968). I Congreso IberoamericanoVirtual de Acuicultura, CIVA 2002 (http://www.civa2002.org), 534-546.

Rodríguez-González, H. (1998), Determinación de parámetros de calidad de los huevecillos del langostino popotillo Macrobrachium tenellum (Smith, 1871), variando la dieta de los reproductores. Bachellor Thesis, Universidad Autónoma de Guadalajara, Guadalajara, Jalisco, México. 
Román-Contreras, R. (1979), Contribución al conocimiento de la biología y ecología de $M$. tenellum (Smith) (Crustácea: Decapoda: Palemonidae). An. Inst. Cienc. del Mar y Limnol., UNAM, 12, 137-160

Sánchez, C., (1976), Desarrollo larval de M. tenellum en El Salvador. In-Conferencia Técnica de la FAO sobre Acuicultura, ed. Pillay, J. Kyoto, Japón, pp. 311-314.

Signoret, P.; Brailovsky, G. and Soto, E. (1997), Comportamiento osmorregulador de Macrobrachium tenellum y Macrobrachium acanthurus (Decapoda: Palemonidae) en diferentes salinidades. Rev. Biol. Trop., 45, 1085-1091.

Sokal, R. R. and Rohlf, F. J. (2000), Biometry. The principles and practice of statistics in biological research. $3^{\text {rd }}$. Ed., Freeman and Company, New York.

Reed, J. and D'Abramo, L. R. (1989), A standard reference diet for crustacean nutrition research. III. Effects on weight gain and amino acid composition of whole body and tail muscle of juvenile prawns Macrobrachium rosenbergii. J. World Aquacult. Soc., 20, 107-113.
Reigh, R. C.; Braden, S. J. and Craig, R. J. (1990), Apparent digestibility coefficients for common feedstuffs in formulated diets for red swamp crayfish, Procambarus clarkii. Aquaculture, 84, 321-334.

Reigh, R. C.; Braden, S. L. and Lapraire, R. J. (1993), Substitution of soya bean protein for fish protein in formulated diets of red swamp crawfish Procambarus clarkii. J. World Aquacult. Soc., 24, 329-338.

Ricker, W. E. (1979), Growth rates and models. In-Fish physiology, volume III, Bioenergetics and growth, eds. Hoar, W. S.; Randall, D. J. and Brett, J. R. Academic Press, New York, USA, pp 599-675.

Rouse, D. B.; Austin, Ch. M. and Medley, P. B. (1991), Progress toward profits? Information on the Australian crayfish. Aquaculture Magazine, 17, 4656.

Tidwell, J. H.; Webster, C. D.; Yancey, D. H. and D'Abramo, L. R. (1993), Partial and total replacement of fish meal with soya bean meal and distillers' by-products in diets for pond culture of the freshwater prawn (Macrobrachium rosenbergii). Aquaculture, 118,119-130. 